\title{
Chemical Durability, Structure Properties and Bioactivity of Glasses $48 \mathrm{P}_{2} \mathrm{O}_{5}-30 \mathrm{CaO}-(22-\mathrm{x}) \mathrm{Na}_{2} \mathrm{O}-\mathrm{xTiO}_{2}$ (With $0<\mathrm{x} \leq 3$; mol\%)
}

\author{
Yassine Er-Rouissi1', Sara Aqdim², Abdeslam El Bouari², Fouzia Hmimid³, Said Aqdim,4* \\ ${ }^{1}$ Faculty of Sciences, Laboratory of Materials Engineering for Environment and Valorization, Hassan II University Ain Chock, \\ Casablanca, Morocco \\ ${ }^{2}$ Faculty of Sciences Ben-M'sik, Laboratory Physical-Chemistry of Applied Materials, Hassan II University, Casablanca, Morocco \\ ${ }^{3}$ Department of Biology, Faculty of Science, Laboratory Health \& Environment, Hassan II University Ain Chock, \\ Casablanca, Morocco \\ ${ }^{4}$ Department of Chemistry, Faculty of Science, Mineral Chemistry Laboratory, Hassan II University Ain Chock, \\ Casablanca, Morocco \\ Email: *said_aq@yahoo.fr
}

How to cite this paper: Er-Rouissi, Y., Aqdim, S., Bouari, A.E., Hmimid, F. and Aqdim, S. (2020) Chemical Durability, Structure Properties and Bioactivity of Glasses $48 \mathrm{P}_{2} \mathrm{O}_{5}-30 \mathrm{CaO}-(22-\mathrm{x}) \mathrm{Na}_{2} \mathrm{O}-\mathrm{xTiO}_{2}$ (With $0<\mathrm{x} \leq 3$; mol\%). Advances in Materials Physics and Chemistry, 10, 305-318. https://doi.org/10.4236/ampc.2020.1012024

Received: October 10, 2020

Accepted: December 21, 2020

Published: December 24, 2020

Copyright $\odot 2020$ by author(s) and Scientific Research Publishing Inc. This work is licensed under the Creative Commons Attribution International License (CC BY 4.0).

http://creativecommons.org/licenses/by/4.0/ (c) (i) Open Access

\begin{abstract}
Phosphate glasses of composition $48 \mathrm{P}_{2} \mathrm{O}_{5}-30 \mathrm{CaO}-(22-\mathrm{x}) \mathrm{Na}_{2} \mathrm{O}-\mathrm{xTiO}$ (with 0 $<\mathrm{x} \leq 3, \mathrm{~mol} \%)$ were prepared by direct melting at $1080^{\circ} \mathrm{C} \pm 20^{\circ} \mathrm{C}$. The chemical durability of these glasses shows an improvement when the $\mathrm{TiO}_{2}$ content varies from 0 to $2 \mathrm{~mol} \%$. The measurements of differential thermal analysis and density, both, indicate the increase of the glass transition temperature and the density. The increase of $\mathrm{Tg}$ leads to an improvement of glass rigidity. $\mathrm{X}$-ray diffraction analysis of the glasses annealed at $650^{\circ} \mathrm{C}$ for $48 \mathrm{~h}$, indicates the appearance of a mixture of metaphosphate and pyrophosphate phases when the $\mathrm{TiO}_{2}$ content varies from 0 to $2 \mathrm{~mol} \%$, the last become majority when the $\mathrm{TiO}_{2}$ content rich $2 \mathrm{~mol} \%$. Nevertheless, when the $\mathrm{TiO}_{2}$ content exceeds $2 \mathrm{~mol} \%$, the analysis, both, by infrared spectroscopy and X-ray diffraction, reveals a radical change of structure with the formation of majorities isolated orthophosphate groups. SEM micrographs illustrated that the number of crystallites increased in the glass network when the $\mathrm{TiO}_{2}$ content increased at the expense of the $\mathrm{Na}_{2} \mathrm{O}$ content. An increase in the $\mathrm{TiO}_{2}$ content beyond $2 \mathrm{~mol} \%$ led to the formation of a larger number of crystallites of different sizes, dominated by small crystallite sizes assigned to majority isolated short orthophosphate groups. This phenomenon led to a decrease in chemical durability and seems to be the main cause promoting the bioactivity of glasses. The results of the bioactivity, after a test in an SBF physiological solution within 15 days, shows, both, the formation of hydroxyapatite and trical-
\end{abstract}


cium phosphate layers, in addition to the layer $\mathrm{Ca}_{2} \mathrm{P}_{2} \mathrm{O}_{7}$, known by its bioactivity, in some samples. The results obtained on the glasses studied make them potential candidates for an application in tissue engineering.

\section{Keywords}

Chemical Durability, Phosphate Glasses, Titan Oxide, Bioactivity, SBF

\section{Introduction}

Several studies have been carried out on phosphate-based glasses as promising materials for various applications in all fields. The properties of phosphate glasses such as low melting point, high thermal expansion coefficient, sealing materials and bioactivity, including the concept of the biomaterials degradation, make them potential candidates for many technological applications [1]-[11]. The bioactivity of phosphate glasses and in particular the property of being completely dissolved in aqueous medium; this degradation concept can be controlled by modifying the intermediate oxides so that the latter are in congruence with the chemical durability and can be used for glasses rich in phosphate and calcium applied as biomaterials [11]-[17]. Calcium phosphate glasses and glass ceramics in the orthophosphate region $\left(\mathrm{CaO} / \mathrm{P}_{2} \mathrm{O}_{5}=0.5-2\right)$ [18] were obtained by using of other oxides such as $\mathrm{Na}_{2} \mathrm{O}, \mathrm{Al}_{2} \mathrm{O}_{3}, \mathrm{Fe}_{2} \mathrm{O}_{3}, \mathrm{ZnO}, \mathrm{MgO}, \mathrm{TiO}_{2}$, which can easily depolymerize $\mathrm{P}_{2} \mathrm{O}_{5}$ oxide from long ultraphosphate $(\mathrm{O} / \mathrm{P}=2.5)$ chains to isolated short orthophosphate chains $(\mathrm{O} / \mathrm{P}=4)$. Our goal is to develop bioactive glasses, focusing particularly on the effect of the substitution of $\mathrm{TiO}_{2}$ to calcium phosphate oxide glasses for use in the medical field. The study of composition glasses $48 \mathrm{P}_{2} \mathrm{O}_{5}-30 \mathrm{CaO}-(22-\mathrm{x}) \mathrm{Na}_{2} \mathrm{O}-\mathrm{xTiO}_{2}$ (with $0<\mathrm{x} \leq 3$; mol\%) as a function of the $\mathrm{TiO}_{2}$ content has shown a rigidity of the glass network in congruence with its biodegradability. The increase in the $\mathrm{TiO}_{2}$ content (with $0<\mathrm{x} \leq 2$; mol\%) in the glass network entrained an increase of the chemical durability, and $\mathrm{Tg}$, followed by an important change from metaphosphate $\left(\mathrm{Q}^{2}\right)$ to pyrophosphate structural units $\left(\mathrm{Q}^{1}\right)$. When the $\mathrm{TiO}_{2}$ content beyond $2 \mathrm{~mol} \%$, the chemical durability undergo a slow decrease and the structure evolve toward majority isolated short orthophosphate units $\left(\mathrm{Q}^{0}\right)$, confirmed by IR spectrum and $\mathrm{X}$-Ray diffraction, SEM micrographs illustrated that the number of crystallites increased in the glass network when the $\mathrm{TiO}_{2}$ content increased at the expense of the $\mathrm{Na}_{2} \mathrm{O}$ content. This indicates that we are near the border between the glass and the crystal [15] [19] [20]. The chemical reactivity of these materials was evaluated after immersion in the simulated body fluid (SBF) at $37^{\circ} \mathrm{C}$ for 15 days. The analysis results seem important for the beginning of the glasses bioactivity.

\section{Experimental Section}

Phosphate glasses are prepared by direct melting of the $\left(\mathrm{NH}_{4}\right) \mathrm{H}_{2} \mathrm{PO}_{4}, \mathrm{CaCO}_{3}$, 
$\mathrm{Na}_{2} \mathrm{O}, \mathrm{TiO}_{2}$ mixture in suitable proportions. The reagents are intimately crushed then introduced into a porcelain crucible. Then, they are heated initially at $300^{\circ} \mathrm{C}$ for $2 \mathrm{~h}$ and then at $500^{\circ} \mathrm{C}$ for $1 \mathrm{~h}$ to complete the decomposition. The reaction mixture is then heated at $900^{\circ} \mathrm{C}$. For 40 minutes and finally at $1080^{\circ} \mathrm{C}$. For 30 minutes in order to obtain a homogeneous liquid. Then it is cast in an aluminum plate previously heated to $200^{\circ} \mathrm{C}$ to avoid thermal shock. Pellets 5 to $10 \mathrm{~mm}$ in diameter and 1 to $3 \mathrm{~mm}$ thick are obtained. The samples were then immersed in distilled water at $90^{\circ} \mathrm{C}$ for 20 days to determine the dissolution rate evaluated from the mass loss as a function of time. Analysis by IR spectroscopy was done in a frequency range of between 400 and $1600 \mathrm{~cm}^{-1}$ with a resolution of $2 \mathrm{~cm}^{-1}$, using a Fourier transform spectrometer. The vitreous state was first evidenced from the shiny and transparency aspect, which was then confirmed by $\mathrm{X}$-ray diffraction (XRD) patterns. Samples glasses were analyzed by X-ray diffraction after an annealing time of $48 \mathrm{~h}$ at $650^{\circ} \mathrm{C}$. Differential thermal analysis (DTA) was performed using a Perkin-Elmer DTA7, at a heating rate of $10^{\circ} \mathrm{C} / \mathrm{min}$ in a flowing nitrogen atmosphere $\left(30 \mathrm{~cm}^{3} / \mathrm{mn}\right)$ with alumina crucibles. The Archimedes method was used to measure the density of glasses using orthophthalate as a floating medium. The microstructures of the sample glasses were characterised by scanning electron microscopy (SEM), equipped with a full system micro-analyser (EDX-EDAX). Glass powder of each sample was soaked in SBF solution at $37^{\circ} \mathrm{C}$ for 21 days.

\section{Results and Discussion}

\subsection{Chemical Durability}

The glass series $48 \mathrm{P}_{2} \mathrm{O}_{5}-30 \mathrm{CaO}-(22-\mathrm{x}) \mathrm{Na}_{2} \mathrm{O}-\mathrm{xTiO}_{2}$ (with $0<\mathrm{x} \leq 3 \mathrm{~mol} \%$ ), was approximated by measuring the dissolution rate $(\mathrm{DR})$ which was defined as the weight loss of the glass expressed in terms $\mathrm{g} \cdot \mathrm{cm}^{-2} \cdot \mathrm{mn}^{-1}$. The DR values reported in Table 1 show a dissolution decrease versus $\mathrm{TiO}_{2}$ contents between 0.5 and 2 mole \%, after their immersion in $100 \mathrm{ml}$ of distilled water, heated at $90^{\circ} \mathrm{C}$ for 21 consecutive days (Figure 1). However, when the $\mathrm{TiO}_{2}$ content exceeds $2 \mathrm{~mol} \%$, there is a relatively significant increase in the dissolution rate. The value

Table 1. The composition and some characteristics of the quaternary glasses $48 \mathrm{P}_{2} \mathrm{O}_{5}-30 \mathrm{CaO}-(22-\mathrm{x}) \mathrm{Na}_{2} \mathrm{O}-\mathrm{xTiO}_{2}$ (with $0<\mathrm{x} \leq 3$; mol\%).

\begin{tabular}{|c|c|c|c|c|c|c|c|c|}
\hline \multirow{2}{*}{$\begin{array}{c}\text { Glass } \\
\text { Sample }\end{array}$} & \multicolumn{4}{|c|}{ Starting Oxide mixtures mol \% } & \multirow{2}{*}{$\begin{array}{l}{[\mathrm{O} / \mathrm{P}]} \\
\text { Ratio }\end{array}$} & \multirow{2}{*}{$\begin{array}{c}\log \left(\mathrm{D}_{\mathrm{R}}\right) \\
\left(\mathrm{g} \cdot \mathrm{cm}^{-2} \cdot \mathrm{min}^{-1}\right) \\
( \pm 0.2)\end{array}$} & $\operatorname{Tg}\left({ }^{\circ} \mathrm{C}\right)$ & $\operatorname{Tc}\left({ }^{\circ} \mathrm{C}\right)$ \\
\hline & $\mathrm{P}_{2} \mathrm{O}_{5}$ & $\mathrm{CaO}$ & $\mathrm{Na}_{2} \mathrm{O}$ & $\mathrm{TiO}_{2}$ & & & \multicolumn{2}{|c|}{$( \pm 2)$} \\
\hline $48 \mathrm{~T} 05$ & 48 & 30 & 21.5 & 0.5 & 3046 & -4.9 & 405 & 495 \\
\hline $48 \mathrm{~T} 10$ & 48 & 30 & 21 & 1 & 3052 & -5.1 & 449 & 498 \\
\hline $48 \mathrm{~T} 15$ & 48 & 30 & 20.5 & 1.5 & 3057 & -5.7 & 473 & 525 \\
\hline $48 \mathrm{~T} 20$ & 48 & 30 & 20 & 2 & 3062 & -6.05 & 476 & 540 \\
\hline $48 \mathrm{~T} 25$ & 48 & 30 & 19.5 & 2.5 & 3067 & -5.9 & 430 & 490 \\
\hline $48 \mathrm{~T} 30$ & 48 & 30 & 19 & 3 & 3072 & -5.5 & 450 & 496 \\
\hline
\end{tabular}




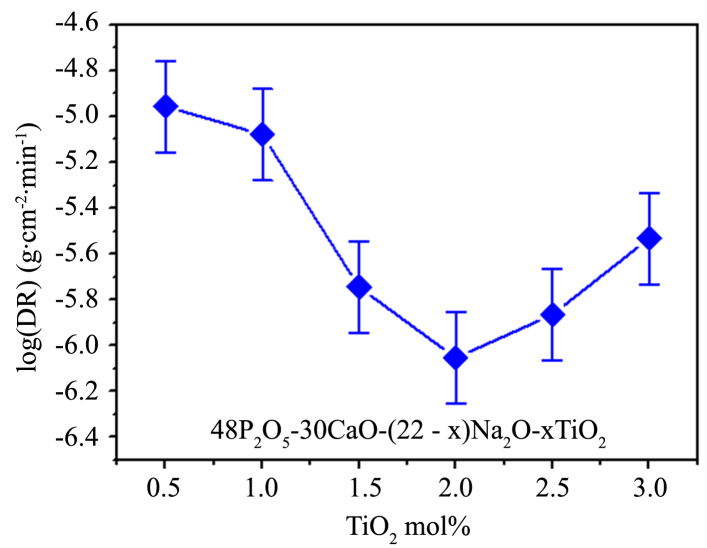

Figure 1. Curve representing the dependency of the chemical durability of the phosphate glasses on the $\mathrm{TiO}_{2}(\mathrm{~mol} \%)$ level.

of leached $\mathrm{pH}$, for different samples, after 21 days, is represented as a function of the $\mathrm{TiO}_{2}$ content (Figure 2), it indicates that the $\mathrm{pH}$ of the solution varies in a range between 3 and $7 \pm 0.5$, values which correspond to the leached $\mathrm{pH}$ of a bioactive glass [18] [21] [22] [23].

\subsection{Density and Molar Volumes}

The Archimedes principle was used to measure the density of glasses using orthophthalate as a floating medium. The density of the glasses was obtained by using the relation (1),

$$
\rho=\left[\frac{m_{\text {air }}}{m_{\text {air }}+m_{\text {ortho }}-m_{\text {(ortho+glass) }}}\right] \rho_{\text {ortho }}
$$

With: $m_{\text {air }}$ the mass of the sample measured in the area.

$m_{\text {ortho }}$ : Orthophthalate mass only.

$m_{\text {(ortho+glass) }}$ : Mass of glass immersed in diethyl orthophthalate.

$\rho_{\text {ortho }}: 1.11422 \mathrm{~g} \cdot \mathrm{cm}^{-3}$.

The density variation of composition glasses are represented in Figure 2. The molar volume and the anionic radius of the oxygen in the glass were determined respectively from the relationships (2) and (3):

$$
\begin{gathered}
V_{0 M}=M / \rho N_{A} N_{0}^{*} \\
r_{\text {cal }}\left(\mathrm{O}^{=}\right)=3 \sqrt{V_{0 M}} / 2
\end{gathered}
$$

With $M=$ molar mass, $\rho=$ density, $N_{A}=$ Avogadro number; $N_{0}^{*}$ number of oxygen atoms in the molecular formula. The value of the molar volume and the oxygen radius were calculated from the approximate hypothesis of close packing of oxygen anions $\mathrm{O}^{2-}$, having $r\left(\mathrm{O}^{2-}\right)$ recapitulated for each composition in Table 2 [1] [15]. As can be seen from Figure 3, density increased with $\mathrm{TiO}_{2}$ content at the expense of $\mathrm{Na}_{2} \mathrm{O}$. This seems obvious since the molar mass of titanium oxide is greater than that of sodium oxide. However, when the $\mathrm{TiO}_{2}$ content becomes greater than $2 \mathrm{~mol} \%$, a decrease in the density is noted [9] [13] [14]. 
Table 2. Glass composition expressed in terms of quaternary system.

\begin{tabular}{ccc}
\hline Glass sample Code & Chemical compositions $(\mathrm{mol} \%)$ & \multicolumn{1}{c}{ Glass compositions inside the ternary diagram } \\
\hline $48 \mathrm{~T} 05$ & $48 \mathrm{P}_{2} \mathrm{O}_{5} \cdot 30 \mathrm{CaO} \cdot 21.5 \mathrm{Na}_{2} \mathrm{O} \cdot 0.5 \mathrm{TiO}_{2}$ & $0.3173\left(\mathrm{Na}_{2} \mathrm{O} \cdot \mathrm{P}_{2} \mathrm{O}_{5}\right) \cdot 0.0096\left(\mathrm{TiO}_{2} \cdot \mathrm{P}_{2} \mathrm{O}_{5}\right) \cdot 0.6731\left(\mathrm{CaO}_{2} \mathrm{P}_{2} \mathrm{O}_{5}\right)$ \\
$48 \mathrm{~T} 10$ & $48 \mathrm{P}_{2} \mathrm{O}_{5} \cdot 30 \mathrm{CaO} \cdot 21 \mathrm{Na}_{2} \mathrm{O} \cdot 1 \mathrm{TiO}_{2}$ & $0.3077\left(\mathrm{Na}_{2} \mathrm{O} \cdot \mathrm{P}_{2} \mathrm{O}_{5}\right) \cdot 0.0192\left(\mathrm{TiO}_{2} \cdot \mathrm{P}_{2} \mathrm{O}_{5}\right) \cdot 0.6731\left(\mathrm{CaO} \cdot \mathrm{P}_{2} \mathrm{O}_{5}\right)$ \\
$48 \mathrm{~T} 15$ & $48 \mathrm{P}_{2} \mathrm{O}_{5} \cdot 30 \mathrm{CaO} \cdot 20.5 \mathrm{Na}_{2} \mathrm{O} \cdot 1.5 \mathrm{TiO}_{2}$ & $0.2982\left(\mathrm{Na}_{2} \mathrm{O} \cdot \mathrm{P}_{2} \mathrm{O}_{5}\right) \cdot 0.02887\left(\mathrm{TiO}_{2} \cdot \mathrm{P}_{2} \mathrm{O}_{5}\right) \cdot 0.6731\left(\mathrm{CaO} \cdot \mathrm{P}_{2} \mathrm{O}_{5}\right)$ \\
$48 \mathrm{~T} 20$ & $48 \mathrm{P}_{2} \mathrm{O}_{5} \cdot 30 \mathrm{CaO} \cdot 20 \mathrm{Na}_{2} \mathrm{O} \cdot 2 \mathrm{TiO}_{2}$ & $0.2884\left(\mathrm{Na}_{2} \mathrm{O} \cdot \mathrm{P}_{2} \mathrm{O}_{5}\right) \cdot 0.0385\left(\mathrm{TiO}_{2} \cdot \mathrm{P}_{2} \mathrm{O}_{5}\right) \cdot 0.6731\left(\mathrm{CaO}_{2} \mathrm{P}_{2} \mathrm{O}_{5}\right)$ \\
$48 \mathrm{~T} 25$ & $48 \mathrm{P}_{2} \mathrm{O}_{5} \cdot 30 \mathrm{CaO} \cdot 19.5 \mathrm{Na}_{2} \mathrm{O} \cdot 2.5 \mathrm{TiO}_{2}$ & $0.2788\left(\mathrm{Na}_{2} \mathrm{O} \cdot \mathrm{P}_{2} \mathrm{O}_{5}\right) \cdot 0.0481\left(\mathrm{TiO}_{2} \cdot \mathrm{P}_{2} \mathrm{O}_{5}\right) \cdot 0.6731\left(\mathrm{CaO}_{2} \cdot \mathrm{P}_{2} \mathrm{O}_{5}\right)$ \\
$48 \mathrm{~T} 30$ & $48 \mathrm{P}_{2} \mathrm{O}_{5} \cdot 30 \mathrm{CaO} \cdot 19 \mathrm{Na}_{2} \mathrm{O} \cdot 3 \mathrm{TiO}_{2}$ & $0.26923\left(\mathrm{Na}_{2} \mathrm{O} \cdot \mathrm{P}_{2} \mathrm{O}_{5}\right) \cdot 0.0576\left(\mathrm{TiO}_{2} \cdot \mathrm{P}_{2} \mathrm{O}_{5}\right) \cdot 0.6731\left(\mathrm{CaO} \cdot \mathrm{P}_{2} \mathrm{O}_{5}\right)$ \\
\hline
\end{tabular}

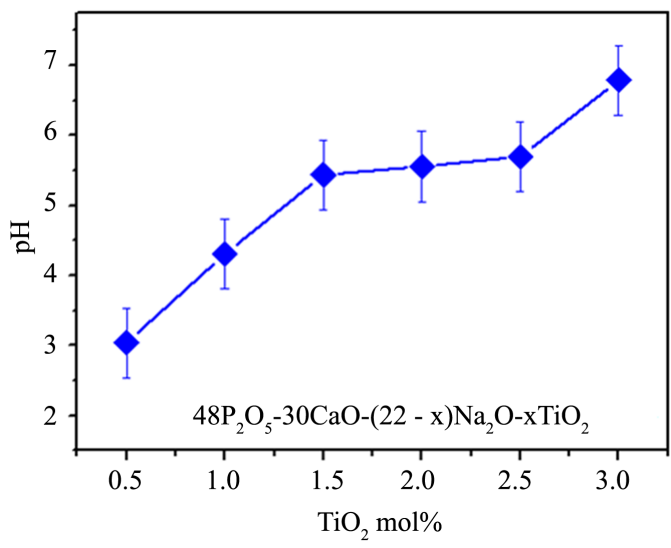

Figure 2. evolution of the lixiviate $\mathrm{pH}$ versus of $\mathrm{TiO}_{2}$ content for 21 days of attack in distilled water at $90^{\circ} \mathrm{C}$.

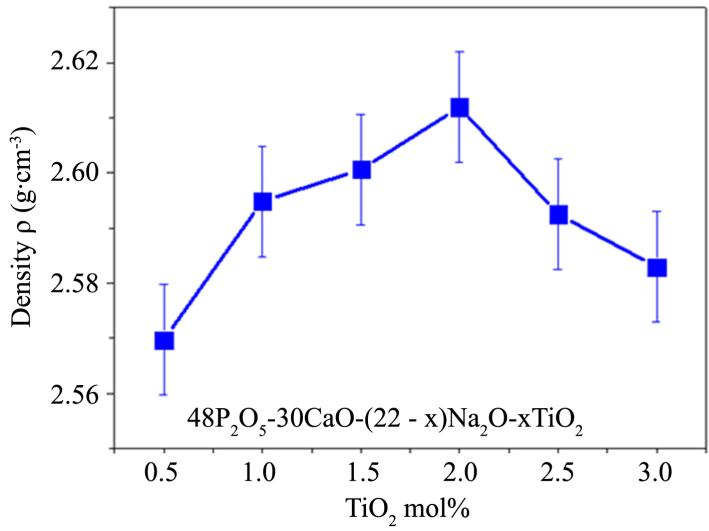

Figure 3. Variation of the Density $(\rho)$ versus $\mathrm{TiO}_{2}$ mol\% along the Glass series $48 \mathrm{P}_{2} \mathrm{O}_{5}-30 \mathrm{CaO}-(22-\mathrm{x}) \mathrm{Na}_{2} \mathrm{O}-\mathrm{xTiO}_{2}$.

\subsection{Infra-Red Spectra}

The infrared spectra of $48 \mathrm{P}_{2} \mathrm{O}_{5}-30 \mathrm{CaO}-(22-\mathrm{x}) \mathrm{Na}_{2} \mathrm{O}-\mathrm{xTiO}_{2}$ series glasses (with 0 $<\mathrm{x} \leq 3$ ) are shown in Figure 4. All the vibration bands of the treated samples are in the frequency range from 1400 to $400 \mathrm{~cm}^{-1}$. Analysis of the infrared spectra obtained for all the glasses shows a wide band at around $510 \mathrm{~cm}^{-1}$ attributed to the vibration mode of the skeleton $\delta(\mathrm{P}-\mathrm{O}-\mathrm{P})$ [1] [3] [9]. The vibration bands located around $754-784 \mathrm{~cm}^{-1}$ are attributed to the vibration mode Vsym (P-O-P) 


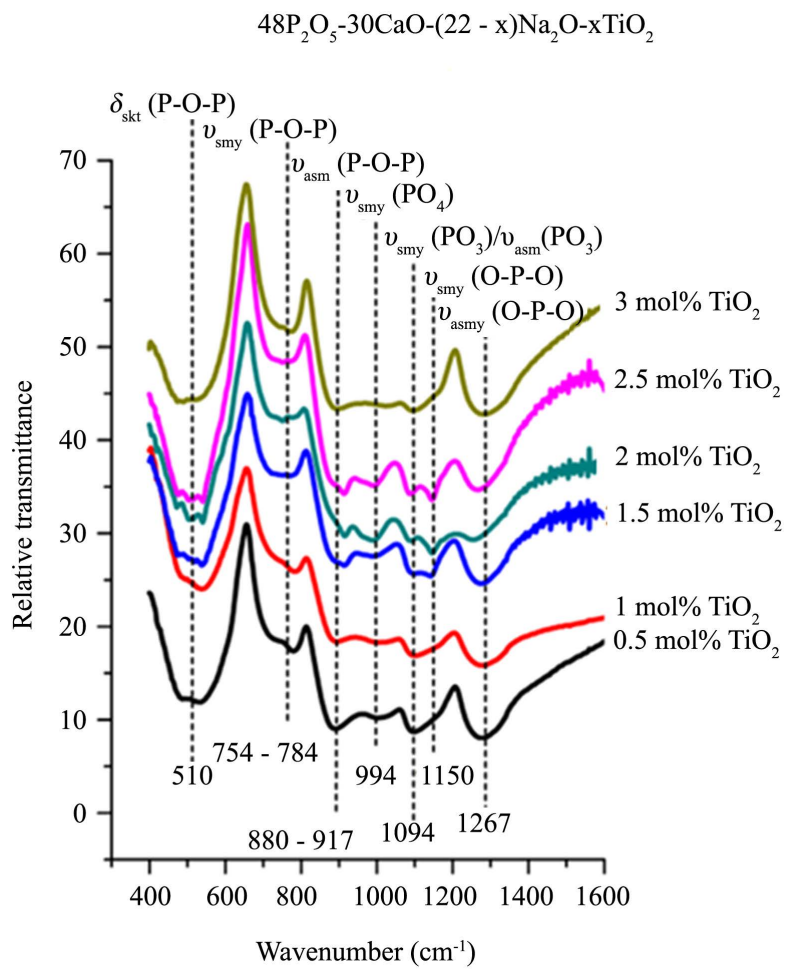

Figure 4. IR spectra of phosphate glasses of composition $48 \mathrm{P}_{2} \mathrm{O}_{5}-30 \mathrm{CaO}-(22-\mathrm{x}) \mathrm{Na}_{2} \mathrm{O}-\mathrm{xTiO}_{2}$.

of pyrophosphate groups $\left(\mathrm{Q}^{1}\right)$, while the bands at around $1094 \mathrm{~cm}^{-1}$ and 1267 $\mathrm{cm}^{-1}$ are respectively assigned to the $\mathrm{Vsym}\left(\mathrm{PO}_{2}\right) / \mathrm{Vasy}\left(\mathrm{PO}_{3}\right)$ of pyrophosphate groups $\left(\mathrm{Q}^{1}\right)$ and vibration mode Vasy $\left(\mathrm{PO}_{2}\right)$ of metaphosphate groups $\left(\mathrm{Q}^{2}\right)[2]$ [4] [5] [9] [12]. The band at around $1150 \mathrm{~cm}^{-1}$, attributed to the stretching vibration Vsym $\left(\mathrm{PO}_{2}\right)$ in $\mathrm{Q}^{1}-\mathrm{Q}^{2}$ units, appears when the $\mathrm{TiO}_{2}$ content increased in the glass network [4] [9] [12], while the intensity of the band $1267 \mathrm{~cm}^{-1}$ attributed to metaphosphates groups $\left(\mathrm{Q}^{2}\right)$ decreased. In the other hand, the band at $880-917 \mathrm{~cm}^{-1}$, attributed to asymmetric vibration Vasy (P-O-P) in the $\mathrm{Q}^{1}$ unit, shift to high frequencies as the $\mathrm{TiO}_{2}$ content increased in the network glass [2] [4] [5] [9] [15]. However, the characteristic vibration band of Vsym $\left(\mathrm{PO}_{4}^{3-}\right)$ in the $\mathrm{Q}^{0}$ unit, located around $994 \mathrm{~cm}^{-1}$, appeared when the $\mathrm{TiO}_{2}$ content becomes greater than $1.5 \mathrm{~mol} \%$, while the band at $1094 \mathrm{~cm}^{-1}$, attributed to the Vsym $\left(\mathrm{PO}_{2}\right) /$ Vasy $\left(\mathrm{PO}_{3}\right)$ vibration mode of pyrophosphate groups, becomes smaller and smaller [9] [24]. Furthermore, the structure deduced from vibrational spectroscopy is compatible with the localization analysis of the compounds (45T05, 45T10, 45T15) inside the ternary diagram given in Figure 5 and Table 3. However, when the $\mathrm{TiO}_{2}$ content increased beyond 1.5 mole\% (45T20, 45T25), we noticed the appearance, in addition to the olygophopshate groups $\left(\mathrm{Q}^{1}-\mathrm{Q}^{2}\right)$, of isolated short ortho phosphate groups $\left(\mathrm{Q}^{\circ}\right)$ [16] [25] which indicated the approach of the border area between glass and crystal, this can be explained by several factors (high $\mathrm{T}_{\mathrm{f}}$ of $\mathrm{TiO}_{2}$, crystallite level in the glass bath, $\mathrm{Ti}+\mathrm{Ca} / \mathrm{P}$ ratio) [15] [20]. 
Table 3. Density and related molar data of the $48 \mathrm{P}_{2} \mathrm{O}_{5}-30 \mathrm{CaO}-(22-\mathrm{x}) \mathrm{Na}_{2} \mathrm{O}-\mathrm{xTiO}_{2}$ system.

\begin{tabular}{|c|c|c|c|c|c|c|c|c|}
\hline \multirow{2}{*}{ Glass sample code } & \multicolumn{4}{|c|}{ Starting oxide mixtures mol \% } & \multirow{2}{*}{$\begin{array}{c}\rho \\
\left(\mathrm{g} \cdot \mathrm{cm}^{-3}\right) \\
( \pm 0.01)\end{array}$} & \multirow{2}{*}{$\begin{array}{c}\text { Molar } \\
\text { mass } \\
\left(\mathrm{g} \cdot \mathrm{mol}^{-1}\right)\end{array}$} & \multirow{2}{*}{$\begin{array}{c}\text { Molar } \\
\text { volume }(\AA \AA 3) \\
\mathrm{Vo}_{\mathrm{M}}=\mathrm{M} /\left[\rho \mathrm{N}_{\mathrm{A}} \mathrm{No}^{\star}\right]\end{array}$} & \multirow{2}{*}{$\begin{array}{c}\text { Calculated oxygen } \\
\text { radius }(\AA) \\
\mathrm{r}_{\text {cal }}\left(\mathrm{O}^{2-}\right)\end{array}$} \\
\hline & $\mathrm{P}_{2} \mathrm{O}_{5}$ & $\mathrm{CaO}$ & $\mathrm{Na}_{2} \mathrm{O}$ & $\mathrm{TiO}_{2}$ & & & & \\
\hline $48 \mathrm{~T} 05$ & 48 & 30 & 21.5 & 0.5 & 2.57 & 98,719 & 21.81 & 1397 \\
\hline $48 \mathrm{~T} 10$ & 48 & 30 & 21 & 1 & 2.59 & 98,809 & 21.58 & 1392 \\
\hline $48 \mathrm{~T} 15$ & 48 & 30 & 20.5 & 1.5 & 2.60 & 98,898 & 21.52 & 1390 \\
\hline $48 \mathrm{~T} 20$ & 48 & 30 & 20 & 2 & 2.61 & 98,988 & 21.40 & 1388 \\
\hline $48 \mathrm{~T} 25$ & 48 & 30 & 19.5 & 2.5 & 2.59 & 990,775 & 21.55 & 1391 \\
\hline $48 \mathrm{~T} 30$ & 48 & 30 & 19 & 3 & 2.58 & 101,564 & 22.13 & 1403 \\
\hline
\end{tabular}

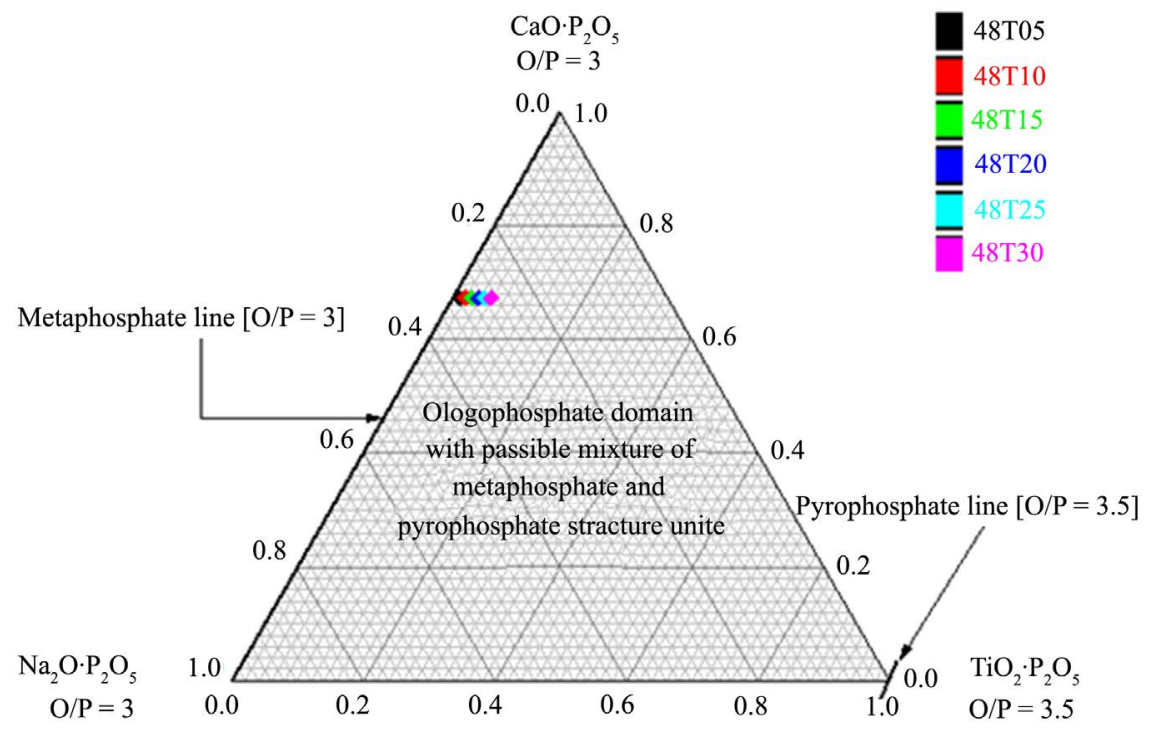

Figure 5. Localization of the investigate glass compositions $48 \mathrm{~T} 05 \rightarrow 48 \mathrm{~T} 25$ within the ternary diagram $\left(\mathrm{CaO} \cdot \mathrm{P}_{2} \mathrm{O}_{5}\right)-\left(\mathrm{Na}_{2} \mathrm{O} \cdot \mathrm{P}_{2} \mathrm{O}_{5}\right)-\left(\mathrm{TiO}_{2} \cdot \mathrm{P}_{2} \mathrm{O}_{5}\right)$. The table gives the corresponding compositions within the quaternary system $\left(\mathrm{P}_{2} \mathrm{O}_{5}-\mathrm{CaO}-\mathrm{Na}_{2} \mathrm{O}-\mathrm{TiO}_{2}\right)$.

\subsection{X-Ray Diffraction and DTA}

As expected, X-ray crystallography confirmed the vitreous nature of all the investigated glass samples studied. In fact, X-ray diffraction pattern (XRD) recordings show the absence of diffraction peaks. DSC of the glasses (Figure 6) indicates both an increase in the glass transition temperature and the crystallization temperature versus $\mathrm{Ti}_{2} \mathrm{O}$ content. When the $\mathrm{Ti}_{2} \mathrm{O}$ content increases from 0.5 to $2 \mathrm{~mol} \%$, the glass transition temperature $(\mathrm{Tg})$ increases in the $405^{\circ} \mathrm{C}-476^{\circ} \mathrm{C}$ range, whereas the crystallization temperature (Tc) increases in the $495^{\circ} \mathrm{C}$ $540^{\circ} \mathrm{C}$ range (see Table 1) [24]. Beyond 2 mole \%, the glass transition temperature $(\mathrm{Tg})$ and the crystallisation temperature $\mathrm{Tc}$ undergo, respectively, a decrease from $476^{\circ} \mathrm{C}$ to $430^{\circ} \mathrm{C}$ and from $540^{\circ} \mathrm{C}$ to $490^{\circ} \mathrm{C}$. The heat treatment of the $48 \mathrm{~T} 15,48 \mathrm{~T} 20$ and $48 \mathrm{~T} 25$ glasses at 650 , gives the XRD patterns shown in Figure 7. These spectra show a structural evolution from metaphosphate to pyrophosphate 


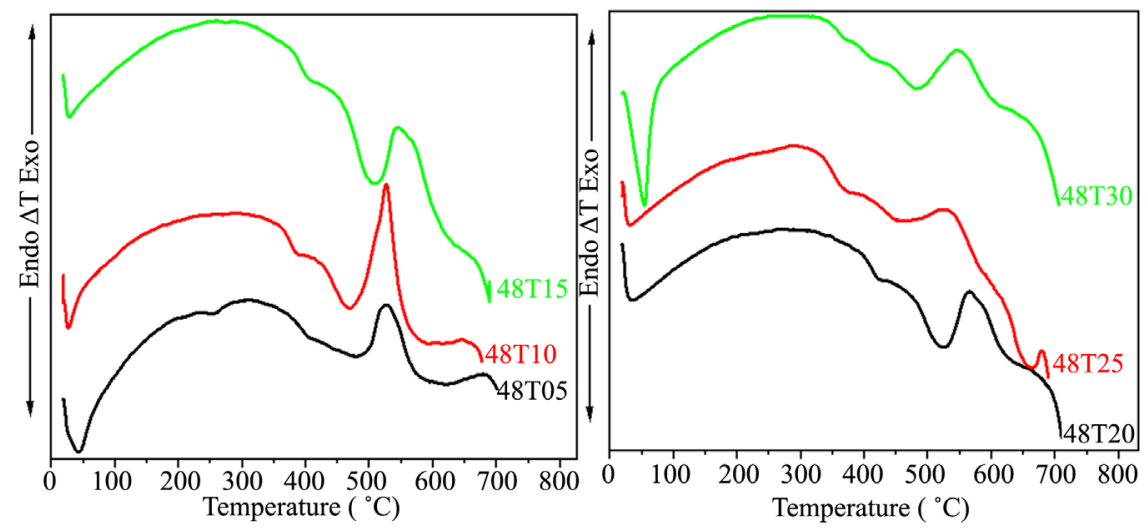

Figure 6. Differential thermal analysis (DTA) of glass compositions $48 \mathrm{P}_{2} \mathrm{O}_{5}-30 \mathrm{CaO}$ $(22-x) \mathrm{Na}_{2} \mathrm{O}-\mathrm{xTiO}$.

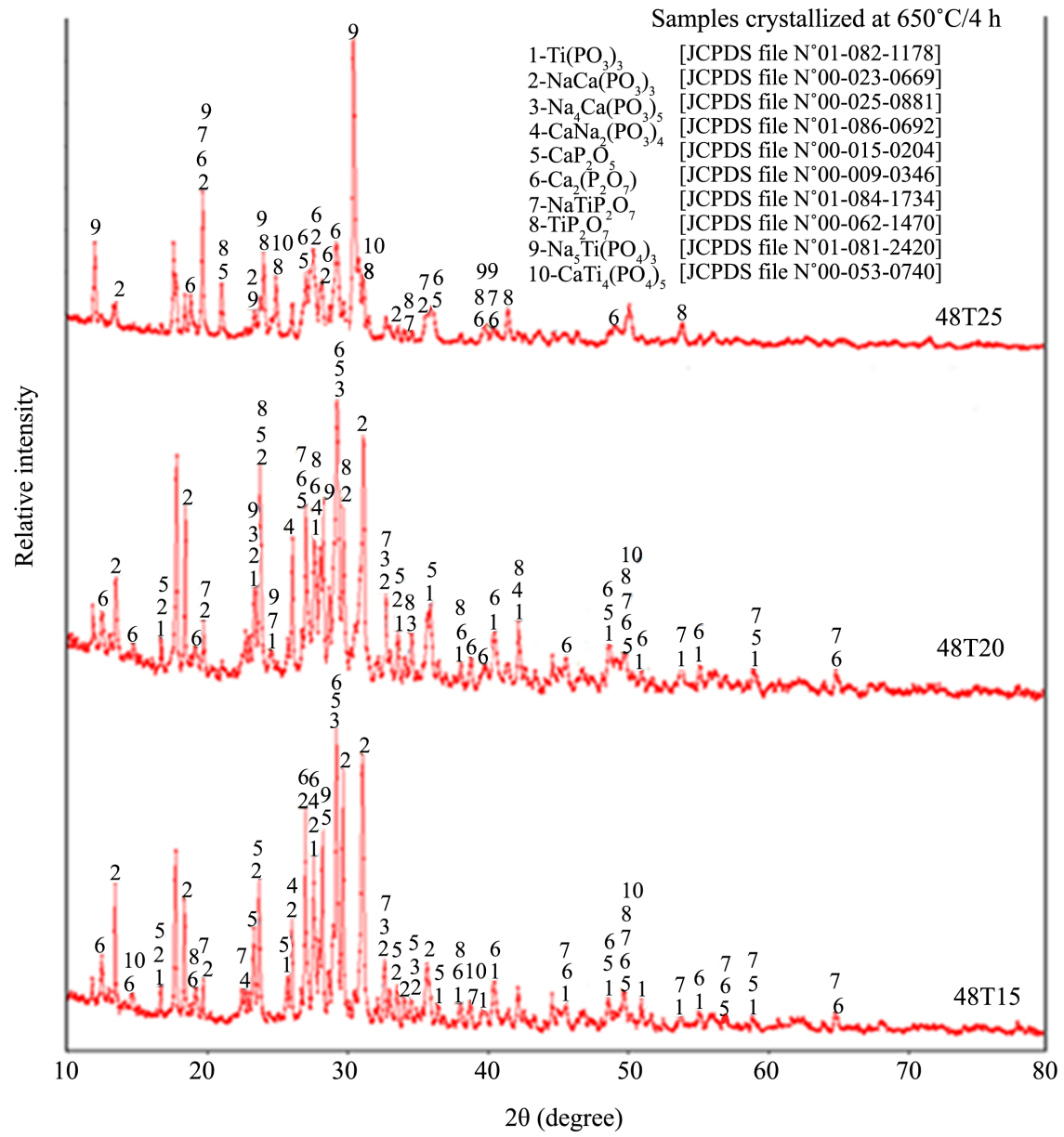

Figure 7. XRD patterns for glass samples $48 \mathrm{~T} 05,48 \mathrm{~T} 15$ and $48 \mathrm{~T} 25$ after heat treatment for $48 \mathrm{hrs}$ under air atmosphere at $650^{\circ} \mathrm{C}$.

and finally to orthophosphates phases. When the $48 \mathrm{~T} 15$ sample was thermally treated at $650^{\circ} \mathrm{C}$, the amorphous phase partially disappeared and majority $\mathrm{Ti}\left(\mathrm{PO}_{3}\right)_{3}$ [JCPDS files $\mathrm{N}^{\circ}: 01-082-1178$ ], $\mathrm{NaCa}\left(\mathrm{PO}_{3}\right)_{3}$ [JCPDS files $\mathrm{N}^{\circ}: 00-23-0669$ ], $\mathrm{Na}_{4} \mathrm{Ca}\left(\mathrm{PO}_{3}\right)_{6}$, [JCPDS files $\mathrm{N}^{\circ}$ : 00-025-0811] and $\mathrm{CaP}_{2} \mathrm{O}_{6}$ [JCPDS files $\mathrm{N}^{\circ}$ : 
00-015-0204] (cyclic metaphosphate $\mathrm{O} / \mathrm{P}=3$ ), with minor $\mathrm{Ca}_{2} \mathrm{P}_{2} \mathrm{O}_{7}$ [JCDDS files $\mathrm{N}^{\circ}:$ 00-009-0346] and $\mathrm{Na}_{5} \mathrm{Ti}_{4}\left(\mathrm{PO}_{4}\right)_{6}$ [JCPDS files $\mathrm{N}^{\circ}: 01-081-2420$ ] phases occurred in the sample. When the $\mathrm{TiO}_{2}$ content increased in the glass (48T20), the heat treatment at $650^{\circ} \mathrm{C}$ caused the formation of $\mathrm{NaTiP}_{2} \mathrm{O}_{7}$ [JCPDS file $\mathrm{N}^{\circ}$ : 01-084-1137-], $\mathrm{Ca}_{2} \mathrm{P}_{2} \mathrm{O}_{7}$ [JCPDS file $\mathrm{N}^{\circ}$ : 00-009-0346] and $\mathrm{TiP}_{2} \mathrm{O}_{7}$ [JCPDS file $\left.\mathrm{N}^{\circ} 00-052-1470\right]$ with some trace of metaphosphate and isolated short orthophosphates phases, and indicated the increase of pyrophosphate phases $(\mathrm{O} / \mathrm{P}=$ 3.5). However, when the $\mathrm{TiO}_{2}$ content exceeded $2 \mathrm{~mol} \%$ (48T25), the heat treatment, at the same temperature, indicated the majority formation of $\mathrm{Na}_{5} \mathrm{Ti}\left(\mathrm{PO}_{4}\right)_{3}$ [JCPDS file $\mathrm{N}^{\circ}$ : 01-081-2421] and $\mathrm{CaTi}_{4}\left(\mathrm{PO}_{4}\right)_{6}$ [JCPDS file $\mathrm{N}^{\circ}:$ 00-053-0740] phases to the detriment of the pyrophosphates and metaphosphate phases [23] [25] [26].

\subsection{SEM Image Analysed}

The SEM micrograph shows the existence of two phases, one crystalline and the other glassy (Figure 8). It also indicates the formation of crystalline phase agglomerates of different sizes [2] [15] [21] [24] [25]. Thus, a structural change is observed from Figure $8(\mathrm{a})$ to Figure $8(\mathrm{~b})$ which presumably indicates the

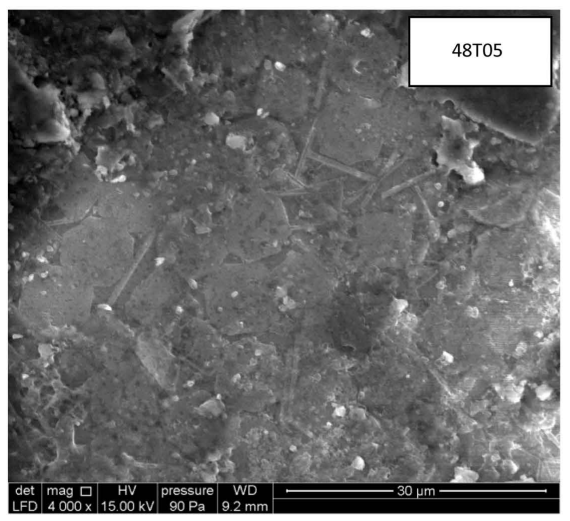

(a)

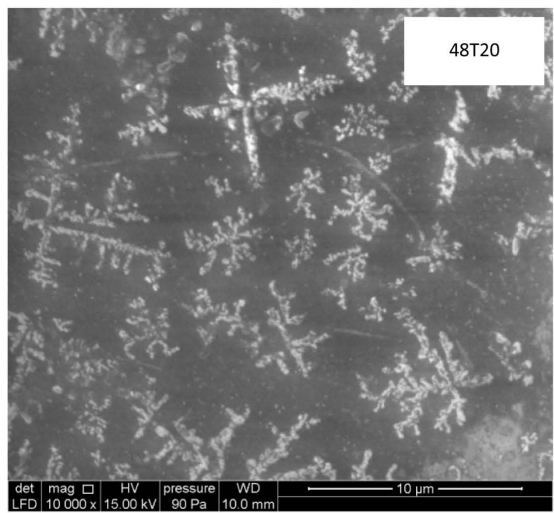

(c)

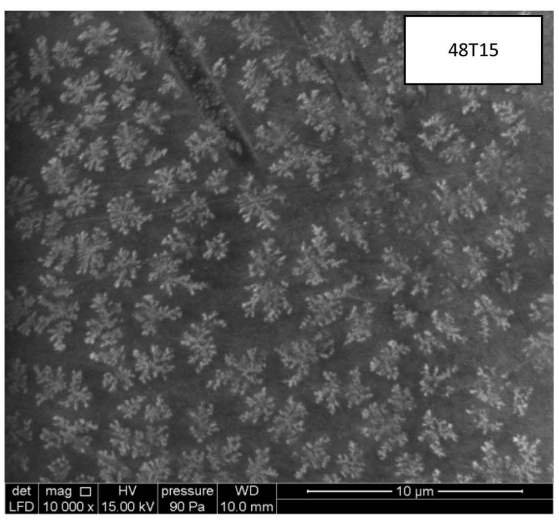

(b)

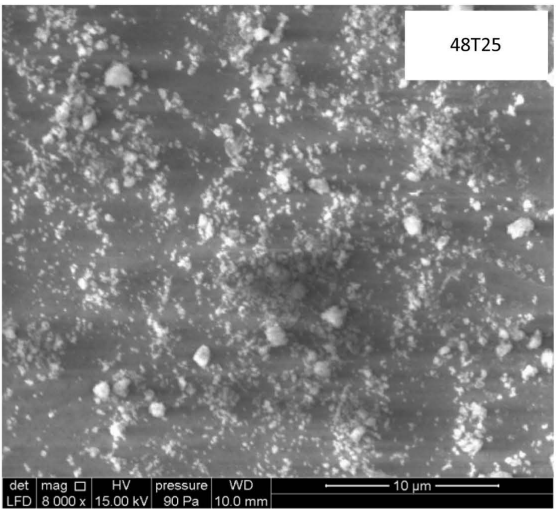

(d)

Figure 8. SEM optical micrograph showing the structural evolution of phosphate glasses from $48 \mathrm{~T} 05$ to $48 \mathrm{~T} 20$. 
formation of the predominant cyclic metaphosphate phases. However, when looking at Figure 8(c) there is a structural mixture between cyclic metaphosphates and, presumably, of short pyrophosphate chains. In Figure $8(d)$, there is a radical change in the structure from the pyrophosphate groups towards predominantly isolated shorter orthophosphate groups. Consequently, the increase of $\mathrm{TiO}_{2}$ content in the glassy network leads to a progressive depolymerization of the cyclic metaphosphate groups towards pyrophosphate groups and finally to isolated short orthophosphate groups [24] [25].

\subsection{In Vitro Bioactivity of Studies Glasses-Surface Analysis Using X-Ray Diffraction}

The study in vitro bioactivity of the prepared glasses was carried out by analyzing X-ray diffraction spectra of the samples after immersion in the simulated body fluid (SBF) for 15 days at $37^{\circ} \mathrm{C}$. The result showed (Figure 9) that for the majority of studied glasses there is formation, both, of hydroxyapatite and tricalcium phosphate layers on the surfaces of the samples in addition to the $\mathrm{Ca}_{2} \mathrm{P}_{2} \mathrm{O}_{7}$ phase known by its bioactivity [16]. When the $\mathrm{TiO}_{2}$ content increases in the glass, the HA and tricalcium phosphate phases become more evident. The number of peaks and their intensities increase, while the peak intensity of the $\mathrm{CaP}_{2} \mathrm{O}_{7}$ phase decreases. The peaks of tricalcium phosphate appear at 22.84 and 24.10 (20) are assigned, respectively, to (241) and (132) reflections [JCPDS file $\mathrm{N}^{\circ}$ 00-033-0297], However the peaks of HA located at 26.40, 28 and 32.83 (20) assign respectively to (002), (102) and (300) reflections [JCPDS file $\mathrm{N}^{\circ} 01-074-0566$ ] [27]. The peaks of $\mathrm{Ca}_{2} \mathrm{P}_{2} \mathrm{O}_{7}$ phase appear at 30 and $31.92(2 \theta)$ are assigned respectively to (211) and (123) reflections [JCPDS file $\mathrm{N}^{\circ} 00-033-0297$ ].

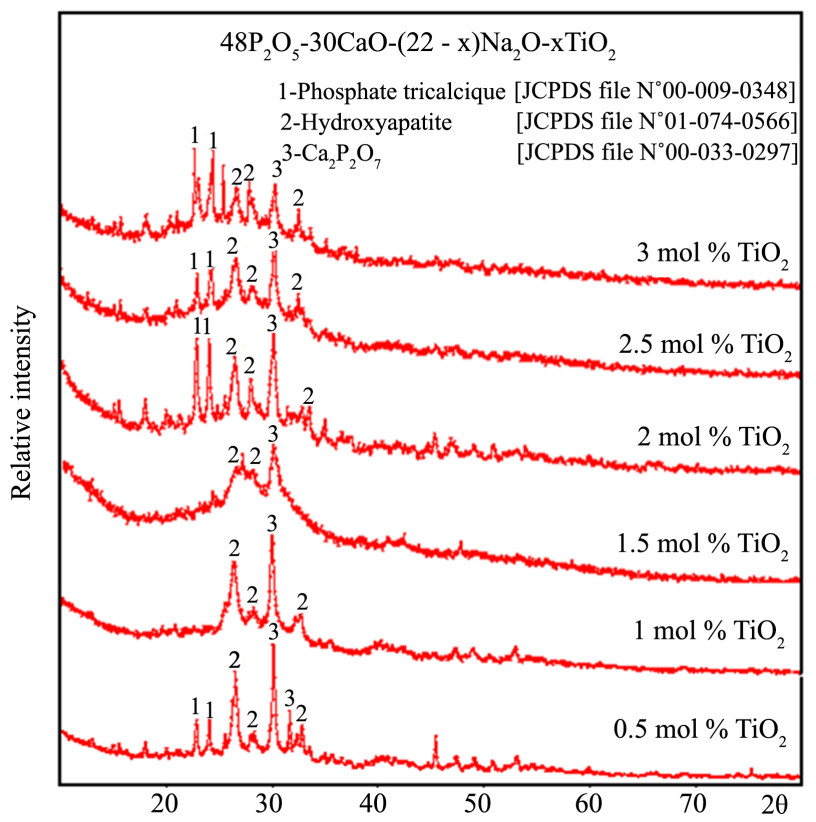

Figure 9. XRD patterns for the surface of the phosphate glasses doped with titanium $48 \mathrm{~T} 05 \rightarrow 48 \mathrm{~T} 30$, after 15 days of immersion in SBF. 
A deep analysis of the spectra obtained seems to suggest that the tricalcium phosphate layer is more important than the hydroxyapatite phase when the $\mathrm{TiO}_{2}$ content reaches $3 \mathrm{~mol} \%$.

\section{Discussion}

Phosphate glasses of composition $48 \mathrm{P}_{2} \mathrm{O}_{5}-30 \mathrm{CaO}-(22-\mathrm{x}) \mathrm{Na}_{2} \mathrm{O}-\mathrm{xTiO}_{2}$ (with $0<\mathrm{x}$ $\leq 3$; mol\%) have been investigated. The structure and the chemical durability have been studies using various techniques such IR, XRD, DSC, SEM... Both $\mathrm{X}$-ray diffraction and IR spectroscopy have confirmed the structure change from metaphosphate to olygophosphates when the $\mathrm{TiO}_{2}$ content increases from 0.5 to $2 \mathrm{~mol} \%$ in the glass. However, beyond $2 \mathrm{~mol} \%$ of $\mathrm{TiO}_{2}$, the appearance of isolated orthophosphates groups is observed. The scanning electron microscope indicated a morphological changing from one cliche to another as the $\mathrm{TiO}_{2}$ content increased from 0.5 to $2.5 \mathrm{~mol} \%$. This change elucidates the passage from cyclic metaphopsphate groups to olygophosphate (mixture meta and pyrophosphate) and finally to isolated short ortho phosphates groups. The variation of transition temperature versus $\mathrm{TiO}_{2}$ content indicated an increase in $\mathrm{Tg}$ from $405^{\circ} \mathrm{C}$ to $430^{\circ} \mathrm{C}$ when the $\mathrm{TiO}_{2}$ content increased from 0.5 to $2 \mathrm{~mol} \%$, elucidating an improvement in the rigidity of the glass [26] [28]. Beyond $2 \mathrm{~mol} \% \mathrm{TiO}_{2}$, the transition temperature $(\mathrm{Tg})$ decreased from $430^{\circ} \mathrm{C}$ to $395^{\circ} \mathrm{C}$, indicating a slight weakness of the glass due to the radical change of structure by the formation, of isolated ortho phosphate groups, confirmed, both, by IR spectroscopy and XRD [12] [15] [20]. The increase of isolated short orthophosphate chains in the glass network, at the expense of olygophosphate chains, when the $\mathrm{Ti}_{2} \mathrm{O}$ content exceeded $2 \mathrm{~mol} \%$, can be explained by the fact that we were close to the border area between crystal and glass [15] [20]. The number of crystallites of different sizes generally increased and exceeded the equilibrium that must be established between the glass bath and the crystallites; hence, we note a significant decrease in chemical durability. At the light of the results obtained, both, for chemical durability, X-ray diffraction and IR spectra analysis $\left(D_{R} \approx 10^{-6}\right.$ $\mathrm{g} \cdot \mathrm{cm}^{-2} \cdot \mathrm{min}^{-1}$, development of isolated orthophosphate groups $\left(\mathrm{PO}_{4}^{3-}\right)$ [20] [23], the chemical reactivity of these materials studied was evaluated after immersion in the simulated body fluid (SBF) at $37^{\circ} \mathrm{C}$ for 15 days. Once in contact with the biological fluids (SBF solution), the bioactive glasses presented the particularity of generating a series of physicochemical reaction to the liquid-glass interface [17] [18] [20]. This series of reactions constitutes the mechanism of bioactivity. The XRD spectra, after test in vitro, indicate the formation of a mixture of hydroxyapatite and tricalcium layers in addition of some traces of calcium pyrophosphate phases, known for its bioactivity [25]. An in-depth analysis of the X-ray spectra obtained, after immersion in the simulated body fluid (SBF), showed that, both, the formation of tricalcium phosphate and of hydroxyapatite layers become more important when the $\mathrm{TiO}_{2}$ content reached $3 \mathrm{~mol} \%$, which, further elucidates that the bioactivity of glasses is like to be greatly successful when once the glass composition is close to the border zone between glass and 
crystal. In addition, bioactivity appeared in all glasses studied, even those which contain traces of isolated short orthophosphate groups ( $\mathrm{x} \leq 2 \mathrm{~mol} \%$ ), this, probably, proves that these last ones are the triggers of bioactivity in the glasses.

\section{Conclusion}

The influence of $\mathrm{TiO}_{2}$ on the glass forming characteristics and properties of $\mathrm{Na}_{2} \mathrm{O}-\mathrm{TiO}_{2}-\mathrm{CaO}-\mathrm{P}_{2} \mathrm{O}_{5}$ glasses has been investigated. The structure and the chemical durability have been studied using various techniques such IR, XRD, DSC, SEM. The variation of the transition temperature versus $\mathrm{TiO}_{2}$ content indicates an increase in $\mathrm{Tg}$ when the $\mathrm{TiO}_{2}$ content increases and indicates an improvement in the rigidity of the glass. SEM micrograph indicates the existence of two phases one crystalline and the other vitreous. The morphological of the phase crystalline change from one micrograph to another as the $\mathrm{TiO}_{2}$ content increases from 0.5 to $2.5 \mathrm{~mol} \%$ and indicates that the structure moves from cyclic metaphosphate and olygophosphate groups to orthophosphate groups. The chemical reactivity of these materials was evaluated after contacting the different glasses with a synthetic physiological fluid (SBF). The XRD spectra of these glasses, after test in vitro, indicate the formation of a mixture of hydroxyapatite and tricalcium layers with some traces of calcium pyrophosphate phases. The presence of these layers is very interested for an eventual biological application in vivo.

\section{Acknowledgements}

The authors wish to thank National Center for Scientific and Technical Research [Division of Technical Support Unit for Scientific Research (TSUSR) Rabat, Morocco] for their assistance to the realization of this work. We also thank Ms. Pr. R. ELOUATIB (Laboratory physic and chemistry of inorganic materials) for the support that has brought us.

\section{Conflicts of Interest}

The authors declare no conflicts of interest regarding the publication of this paper.

\section{References}

[1] Aqdim, S., Sayouty, E.H., Elouadi, B. and Greneche, J.M. (2012) Chemical Durability and Structural Approach of the Glass Series (40-y) $\mathrm{Na}_{2} \mathrm{O}-\mathrm{yFe}_{2} \mathrm{O}_{3}-5 \mathrm{Al}_{2} \mathrm{O}_{3}$ $55 \mathrm{P}_{2} \mathrm{O}_{5}$-by IR, X-Ray Diffraction and Mössbauer Spectroscopy. IOP Conference Series: Materials Science and Engineering, 28, 012003. https://doi.org/10.1088/1757-899X/28/1/012003

[2] Aqdim, S. and Ouchetto, M. (2013) Elaboration and Structural Investigation of Iron (III) Phosphate Glasses. Advances in Materials Physics and Chemistry, 3, 332-339. http://dx.doi.org/10.4236/ampc.2013.38046

[3] Lai, Y.M., Liang, X.F., Yang, S.Y., Wang, J.X. and Zhang, B.T. (2012) Raman Spectra Study of Iron Phosphate Glasses with Sodium Sulfate. Journal of Molecular Struc- 
ture, 1013, 134-137. https://doi.org/10.1016/j.molstruc.2012.01.025

[4] Morikawa, H., Lee, S., Kasuga, T. and Brauer, D.S. (2013) Effects of for Calcium Substitution in $\mathrm{P}_{2} \mathrm{O}_{5}-\mathrm{CaO}-\mathrm{TiO}_{2}$ Glasses. Journal of Non-Crystalline Solids, 380, 53-59. https://doi.org/10.1016/j.jnoncrysol.2013.08.029

[5] Chabbou, Z. and Aqdim, S. (2014) Chemical Durability and Structural Proprieties of the Vitreous Part of the System xCaO- $(40-\mathrm{x}) \mathrm{ZnO}-15 \mathrm{Na}_{2} \mathrm{O}-45 \mathrm{P}_{2} \mathrm{O}_{5}$. Advances in Materials Physics and Chemistry, 4, 179-186. http://dx.doi.org/10.4236/ampc.2014.410021

[6] Bengisu, M., Brow, R.K., Yilmaz, E., Moguš-Milanković, A. and Reis, S.T. (2006) Aluminoborate and Aluminoborosilicate Glasses with High Chemical Durability and the Effect of $\mathrm{P}_{2} \mathrm{O}_{5}$ Additions on the Properties. Journal of Non-Crystallinesolids, 352, 3668-3676. https://doi.org/10.1016/j.jnoncrysol.2006.02.118

[7] Day, D.E., Wu, Z., Ray, C.S. and Hrma, P. (1998) Chemically Durable Iron Phosphate Glass Wasteforms. Journal of Non-Crystalline Solids, 241, 1-12. https://doi.org/10.1016/S0022-3093(98)00759-5

[8] Bingham, P.A. and Hand, R.J. (2005) Vitrified Metal Finishing Wastes: I. Composition, Density and Chemical Durability. Journal of Hazardous Materials, 119, 125-133. https://doi.org/10.1016/j.jhazmat.2004.11.014

[9] Shaim, A. and Et-Tabirou, M. (2003) Role of Titanium in Sodium Titanophosphate Glasses and a Model of Structural Units. Materials Chemistry and Physics, 80, 63-67. https://doi.org/10.1016/S0254-0584(02)00087-1

[10] McLaughlin, J.C., Tagg, S.L., Zwanziger, J.W., Haeffner, D.R. and Shastri, S.D. (2000) The Structure of Tellurite Glass: A Combined NMR, Neutron Diffraction, and X-Ray Diffraction Study. Journal of Non-Crystalline Solids, 274, 1-8. https://doi.org/10.1016/S0022-3093(00)00199-X

[11] Weiss, D.S.L., Torres, R.D., Buchner, S., Blunk, S. and Soares, P. (2014) Effect of Ti and Mg Dopants on the Mechanical Properties, Solubility, and Bioactivity in Vitro of a Sr-Containing Phosphate Based Glass. Journal of Non-Crystalline Solids, 386, 34-38. https://doi.org/10.1016/j.jnoncrysol.2013.11.036

[12] Brow, R.K., Click, C.A. and Alam, T.M. (2000) Modifier Coordination and Phosphate Glass Networks. Journal of Non-Crystalline Solids, 274, 9-16. https://doi.org/10.1016/S0022-3093(00)00178-2

[13] Rajendran, V., Devi, A.G., Azooz, M. and El-Batal, F.H. (2007) Physicochemical Studies of Phosphate Based $\mathrm{P}_{2} \mathrm{O}_{5}-\mathrm{Na}_{2} \mathrm{O}-\mathrm{CaO}-\mathrm{TiO}_{2}$ Glasses for Biomedical Applications. Journal of Non-Crystalline Solids, 353, 77-84. https://doi.org/10.1016/j.jnoncrysol.2006.08.047

[14] Kiani, A., Hanna, J.V., King, S.P., Rees, G.J., Smith, M.E., Roohpour, N. and Knowles, J.C. (2012) Structural Characterization and Physical Properties of $\mathrm{P}_{2} \mathrm{O}_{5}$ $\mathrm{CaO}-\mathrm{Na}_{2} \mathrm{O}-\mathrm{TiO}_{2}$ Glasses by Fourier Transform Infrared, Raman and Solid-State Magic Angle Spinning Nuclear Magnetic Resonance Spectroscopies. Acta Biomaterial, 8, 333-340. https://doi.org/10.1016/j.actbio.2011.08.025

[15] Errouissi, Y., Z. Chabbou, N. Beloued, S. Aqdim and Aqdim, S. (2017) Chemical Durability and Structural Properties of $\mathrm{Al}_{2} \mathrm{O}_{3}-\mathrm{CaO}-\mathrm{Na}_{2} \mathrm{O}-\mathrm{P}_{2} \mathrm{O}_{5}$ Glasses Studied by IR Spectroscopy, XRD and SEM. Advances in Materials Physics and Chemistry, 7, 353-363. https://doi.org/10.4236/ampc.2017.710028

[16] Moss, R.M., Abou Neel, E.A., Pickup, D.M., Twyman, H.L., Martin, R.A., Henson, M.D., Barney, E.R., Hannon, A.C., Knowles, J.C. and Newport, R.J. (2010) The Effect of Zinc and Titanium on the Structure of Calcium-Sodium Phosphate Based Glass. Journal of Non-Crystalline Solids, 356, 1319-1324. 
https://doi.org/10.1016/j.jnoncrysol.2010.03.006

[17] Pardini, A. (2007) Laboration et Analyses Structurales de Bioactifs Macroporeux. These de Doctorat, Université de Valenciennes et du Hainaut Cambrés, Valenciennes.

[18] Mullier, C. (2011) Synthese et Caracterisation de biomatériaux phosphocalciques multiphases dopés ou non avec des inhibiteurs de la Résorption Osseuse, These de Doctorat, Faculté des Sciences \& Techniques, Université de Nantes, France.

[19] Makhlouk, R., Beloued, N. and Aqdim, S. (2018) Study of Chromium-Lead-Phosphate Glasses by XRD, IR, Density and Chemical Durability. Advances in Materials Physics and Chemistry, 8, 269-280. https://doi.org/10.4236/ampc.2018.86018

[20] Beloued, N., Chabbou, Z. and Aqdim, S. (2016) Correlation between Chemical Durability Behaviour and Structural Approach of the Vitreous Part of the System $55 \mathrm{P}_{2} \mathrm{O}_{5}-2 \mathrm{Cr}_{2} \mathrm{O}_{3}-(43-\mathrm{x}) \mathrm{Na}_{2} \mathrm{O}-\mathrm{xPbO}$. Advances in Materials Physics and Chemistry, 6, 149-156. http://dx.doi.org/10.4236/ampc.2016.66016

[21] Lakhkar, N.J., Park, J.-H., Mordan Vehid Salih, N.J., Wall, I.B., Kim, H.-W., King, S.P., Hanna, J.V., Martin, R.A., Addison, O., Mosselmans, J.F.W. and Knowles, J.C. (2012) Titanium Phosphate Glass Microspheres for Bone Tissue Engineering. Acta Biomaterialia, 8, 4181-4190. https://doi.org/10.1016/j.actbio.2012.07.023

[22] Cédric, B. (2008) Elaboration et Caractérisation d'un Hybride Organominéral à Base de Polycaprolactone et de Bioverre sous Forme de Mousse Macroporeuse Pour la Régénération Osseuse. Thèse d'Université, Specialité Sciences des Materiaux, Ecole Doctorale des Sciences Fondamentales, France.

[23] Melba, N., Ginebra, M.-P., Clement, J., Martı'nez, S., Avila, G. and Planell, J.A. (2003) Physicochemical Degradation of Titania-Stabilized Soluble Phosphate Glasses for Medical Applications. Journal of the American Ceramic Society, 86, 1345-1352. https://doi.org/10.1111/j.1151-2916.2003.tb03474.x

[24] Monem, A.S., El Batal, H.A., Khalil, E.M.A., Azooz, M.A. and Hamdy, Y.M. (2008) In Vivo Behavior of Bioactive Phosphate Glass-Ceramics from the System $\mathrm{P}_{2} \mathrm{O}_{5}$ $\mathrm{Na}_{2} \mathrm{O}-\mathrm{CaO}$ Containing $\mathrm{TiO}_{2}$. Journal of Materials Science: Materials in Medicine, 19, 1097-1108. https://doi.org/10.1007/s10856-007-3044-3

[25] El Batal, H.A., Khalil, E.M.A. and Hamdy, Y.M. (2008) In Vitro Behavior of Bioactive Phosphate Glass-Ceramics Fromthe System $\mathrm{P}_{2} \mathrm{O}_{5}-\mathrm{Na}_{2} \mathrm{O}-\mathrm{CaO}$ Containing Titania. Ceramics International, 35, 1195-1204.

https://doi.org/10.1016/j.ceramint.2008.06.004

[26] Ali Abou Neel, E., Chrzanowski, W. and Campbell Knowles, J. (2008) Effect of Increasing Titanium Dioxide Content on Bulk and Surface Properties of PhosphateBased Glasses. Acta Biomaterialia, 4, 523-534.

https://doi.org/10.1016/j.actbio.2007.11.007

[27] Mathew, M., Schroeder, L.W., Dickens, B. and Brown, W.E. (1977) The Crystal Structure of $\alpha-\mathrm{Ca}_{3}\left(\mathrm{PO}_{4}\right)_{2}$. Acta Crystallographica Section B, 33, 1325-1333. https://doi.org/10.1107/S0567740877006037

[28] Beloued, N., Makhlouk, R., Er-Rouissi, Y., Taibi, M., Sajieddine, M. and Aqdim, S. (2019) Relationship between Chemical Durability, Structure and the Ionic-Covalent Character of $\mathrm{Me}-\mathrm{O}-\mathrm{P}$ Bond $(\mathrm{Me}=\mathrm{Cr}, \mathrm{Fe})$, in the Vitreous Part of the System $60 \mathrm{P} 2 \mathrm{O} 5-2 \mathrm{Cr}_{2} \mathrm{O}_{3}-(38-\mathrm{x}) \mathrm{Na}_{2} \mathrm{O}-\mathrm{xFe}_{2} \mathrm{O}_{3}$ (with $\left.3 \leq \mathrm{x} \leq 33 \mathrm{~mol} \%\right)$. Advances in Materials Physics and Chemistry, 9, 199-209. 